164-179

J. Nat. Hist. Mus. Vol. 30, 2016-18

\title{
Diversity and conservation threats of water birds in and around Barandabhar corridor forest, Chitwan, Nepal
}

\author{
Jagan Nath Adhikari ${ }^{1,3}$, Bishnu Prasad Bhattarai ${ }^{2} \bowtie$ and Tej Bahadur Thapa ${ }^{2}$ \\ ${ }^{1}$ Department of Zoology, Birendra Multiple Campus, Tribhuvan University, Chitwan, Nepal \\ ${ }^{2}$ Central Department of Zoology, Tribhuvan University, Kirtipur, Kathmandu, Nepal \\ ${ }^{3}$ Himalayan Environment \& Public Health Network (HEPHN), Bharatpur, Chitwan, Nepal \\ bpbhattarai@cdztu.edu.np
}

\begin{abstract}
Wetlands provide major ecological services for feeding and breeding places of a large number of water birds in many parts of the globe and also play a vital role in conservation of threatened species. Wetlands in Nepal support a total of $27 \%$ of nationally threatened birds. Barandabhar forest is only one vertical (south-north) bio-corridor that links two different ecosystems, CNP and the Mahabharat hill range. Eight wetlands were selected for water birds monitoring by using area search and point count methods to explore the diversity and conservation threats of water birds in Barandabhar corridor forest. This study recorded 3664 individuals of water birds belonging to 54 species, 11 orders and 13 families in which the highest numbers of the species were belonged to order Anseriformes (17 species). The diversity of water birds in eight different wetlands showed the highest diversity in Rapti river $(H=3.403)$, followed by Beeshazari lake system $(H=3.401)$, Batulpokari lake area $(H=3.377)$ and the rest of others. The least diversity of water birds was found in Gundremandre lake $(H=2.210)$. Similarly, the species dominance was more in Gundremandre lake $(D=0.189)$ than Beeshazari $(D=0.046)$ and Batulpokhari $(D=0.042)$. The species richness in various habitats association with wetlands showed that Shorea forest association was utilized very less as compared to its availability. Fishermen ( $r$ $=-0.391, t=10.6, P<0.0001)$ and livestock pressure $(r=-0.276, t=6.63, P=0.0009)$ caused the significant negative impact on the occurrence of water birds in many parts of the study sites. The study suggests that annual flooding in the rivers (e.g., Rapti, Budhirapti and Khageri rivers), human disturbance (e.g., livestock grazing and fishing), habitat loss and degradation, declining water quality and quantity caused by eutrophication and chemical pollution are the major threats of water bird communities in Barandabhar corridor forest.
\end{abstract}

Keywords: Barandabhar, water birds, wetlands, diversity

\section{INTRODUCTION}

Nepal supports $8.87 \%$ of the global bird species due to its landscape heterogeneity (DNPWC, 2017). A total of 887 species has been recorded from Nepal, among them, 37 are globally threatened species, 19 near threatened species and 15 restricted-range species (DNPWC, 2017; IUCN, 2017). Nepal has only one endemic bird named Spiny babbler (Turdoides nipalensis). According to NPWC Act 1973, nine species of birds are Nationally Protected and 111 birds have enlisted in CITES category (DNPWC, 2017). More than 15\% of the total birds 
(130 species) have enlisted in nationally threatened category. Habitat degradation and loss are the major threats (86\%) to the birds. Till date, eight species of the birds have extinct from Nepal (Baral et al., 2012).

Wetlands provide a major ecosystem services for feeding and breeding places of a large number of threatened birds, mammals, reptiles, amphibians and fishes and also play a vital role in conservation of those species. Freshwater wetlands hold more than $40 \%$ bird species of the entire world and $12 \%$ of all animal species (Paracuellos, 2006). Wetlands of Asia support at least $20 \%$ of the threatened bird species including a large number of migratory and resident bird species (Kumar et al., 2005; Paracuellos, 2006). Birds are the most prominent and significant component of freshwater wetland ecosystems and their presence or absence may indicate the ecological conditions or health of the wetlands (Rajpar \& Zakaria, 2010). Wetland of Nepal supports a total of $40(27 \%)$ nationally threatened birds (DNPWC, 2017). About six percentage of total global land is covered by water however Nepal occupies approximately $5 \%(743,500 \mathrm{ha})$ of the total area. Out of the total wetland area, 60,561 ha have been declared as the Ramsar sites for wetland preservation. Now, Nepal has ten Ramsar sites (Koshi Tappu, Beeshazari and associated lakes, Ghodaghodi Lake area, Jagadishpur Reservoir, Gokyo and associated lakes, Gosaikunda and associated lakes, Phoksundo Lake, Rara Lake, Mai Pokhari and Lake clusters of Pokhara Valley) (NLCDC, 2017).

The Chitwan National Park (CNP) harbors a spectacular bird life. The Fresh water swamp of Rapti and Khageri river flood plain stands with Sal (Shorea robusta) and Khair (Acacia catechu) vegetation and the profuse aquatic vegetation are the prime habitats for rich micro and macro living forms including many species of snails, fishes and herpetofauna. Such abundant food renewed each year by floodwater of Narayani and Rapti rivers, has been a suitable habitat for resident water birds and also attracting thousands of migratory water birds every year. More than 600 species of birds have been recorded in CNP (CNP, 2017; Bhattarai, 2012). Barandabhar forest is only one vertical (south-north) bio-corridor that links two different ecosystems, CNP and the Mahabhrat hill range. Furthermore, many popular lakes (Beeshhazari lake system, declared as a Ramsar sites in 2003, Batulpokhari lake, Rhino lake, Gundremandre lake) and Rapti river, Khageri river, Budhirapti and Devanagar khola etc. supports the many wetland dependent birds and other animals. These wetlands are under grave threats due to high pressure of people from two sides (east and west) of BCF. Wetlands have been facing a serious eutrophication problem that significantly decreases the quantity (shrinking area of wetlands) and quality (physicochemical parameters) of water. Therefore, the present study was designed to explore the diversity and conservation threats of water birds in Barandabhar corridor forest (BCF).

\section{MATERIALS AND METHODS}

\section{Study area}

The Barandabhar Corridor Forest (BCF), located in between $27^{\circ} 34^{\prime}$ to $27^{\circ} 40^{\prime} \mathrm{N}$ latitude and $84^{\circ} 21^{\prime}$ to $84^{\circ} 28^{\prime} \mathrm{E}$ longitude is a functional bio-corridor that connects two different ecosystems of lowland Chitwan National Park and the highland Mahabharat range in central Nepal. This project area covers $166 \mathrm{~km}^{2}$ area including forests, grasslands, water bodies and associated 
farmlands (approx. $300 \mathrm{~m}$ from forest boundary) (fig. 1). The forest is regarded as the only one remaining wildlife corridor in the central Nepal that links the lowland to mid-hill ecosystems (Lamichhane et al., 2016). Due to high biodiversity including birds, this corridor forest and wetlands have been delineated as the Important Bird and Biodiversity Areas (NP02-IBAs) among the 32 IBAs in Nepal (Baral \& Inskipp, 2005). The East-West Highway bisects the Barandabhar Corridor Forest into two executive jurisdictions. The forest south of the highway is managed under the patronage of Chitwan National Park's buffer zone, while the northern part is under the patronage of Chitwan district forest office.

The CNP, the world heritage site, including BCF supports rare and threatened fauna such as more than 70 mammal species, 600 bird species, 56 species of herpetofauna, 156 species of butterflies and 120 species of fish (CNP, 2017). The BCF is dominated by almost monotypic stands of Shorea robusta and small fragments of riverine and mixed-hardwood forests (NTNC, 2003; Thapa, 2003). Majority areas of BCF comprise Shorea (Sal) forest, which extends up to the foothills of the Mahabharat range (Lamichhane et al., 2016; Thapa, 2011). BCF is also rich in wetlands that are the pristine habitats for the wetland dependent birds. The major wetlands of this area are four rivers (Narayani, Rapti, Budhirapti, Khageri and Devnagar Khola) and lakes (Beeshazari lake- a Ramsar site, Batulpokhari, Rhino lake and association, Gundremandre lake system) (Thapa, 2011). 


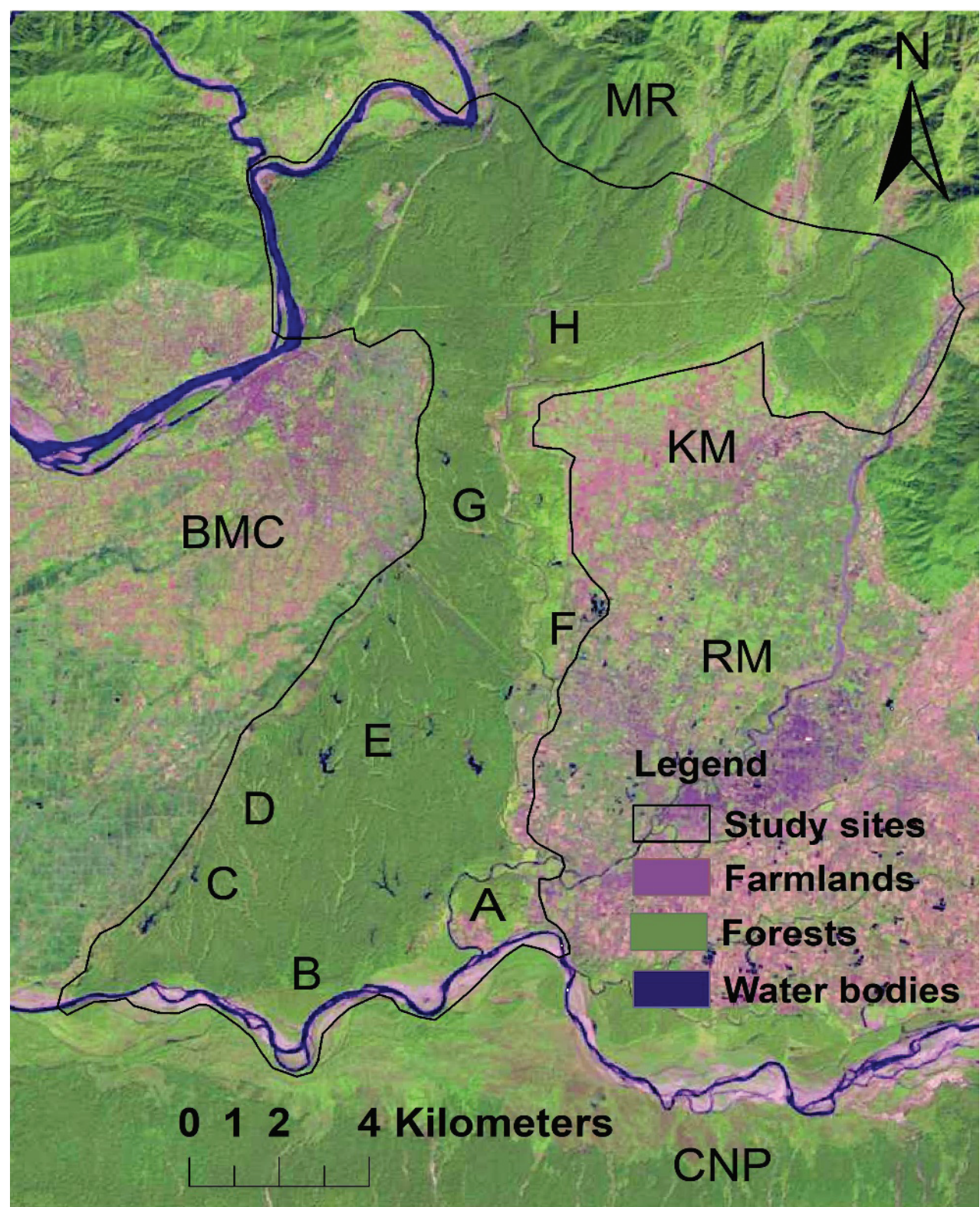

FIG. 1. Map of Barandabhar corridor forest: the study area, showing major study sites ( $A=B$ udhirapti river, $B=$ Rapti river, $C=$ Batulpokhari lake area, $D=$ Devnagar khola, $E=$ Beeshhazari river system, $F=$ Khageri river basin, $G=R$ hino lake area, $H=G$ undremandre lake area. Here, CNP= Chitwan National Park, MR= Mahabharat Range, BMC= Bharatpur Metropolitan City, KM= Kalika Municipality, RM= Ratnanagar Municipality). 


\section{Data collection}

Birds were surveyed using birding routes (BR) and area searches (AS) method for the areas considered as the hotspots of birds during November 2016 to October 2017. Eight hotspots areas (major wetlands of BCF) were identified for the monitoring of water birds (Bibby et al., 2000; Dieni \& Jones, 2002). The eight wetlands under this study are: Budhirapti river (A), Rapti river (from Khorsor to Ghatghain) (B), Batulpokari lake area (C), Devnagar stream (D), Beeshazari lakes system (E), Khageri river (F), Rhino lake area $(G)$, Gundremandre lake area $(\mathrm{H})$. Narayani river was excluded as this part of river is highly disturbed by Narayangarh city. In each lake, certain points were fixed at its periphery for the bird monitoring and in the rivers, a birding route was fixed and the birds were recorded at an interval of $100 \mathrm{~m}$, with the help of binoculars. Direct observation method ("look-see" counting method) was used to identify and record the individuals of bird species (Bibby et al., 2000; Sigdel, 2009). During the survey, the number of individuals, associated habitat types, human disturbance indicators such as number of livestock grazing, number of fishermen etc. were recorded in standard field data sheet. Birds were monitored early in the morning from $6 \mathrm{AM}$ to $10 \mathrm{AM}$ and in the evening from 4 PM to 6 PM (Bibby et al., 2000; Sigdel, 2009).

\section{Data analysis}

The collected data were entered into MsExcel and further statistical analyses were performed in S-Plus and the various indices of species diversity were determined in PAST V 3.18 (Hammer et al., 2001). These diversity indices include Simpson's dominance and diversity, Shannon, Evenness indices, Jacob's Equitability index.

\section{RESULTS AND DISCUSSION}

\section{Species diversity}

This study recorded 3664 individuals of water bird belonging to 54 species, 11 orders and 13 families in Barandabhar corridor forest. The highest number of the species belonged to order Anseriformes (17 species) followed by Pelecaniformes (11 species), Coraciiformes (6 species), Gruiformes (6 species) and so on (table 1, fig. 2). Earlier studies of birds in Koshi Tappu Wildlife Reserve described a total of 485 bird species including residents and migrants that represents 61 bird families of the world. The study showed that the highest number of bird species from the Muscicapidae (44 species) followed by Accipitridae (42 species), Sylviidae (40), Corvidae (31), Passeridae (31), Anatidae (28) and Scolopacidae (20) (Baral, 2005). However, Koshi Tappu had a large number of wetland dependent birds compared to BCF. Bhattarai (2012) reported four species of Ciconiidae, Lesser adjutant stork (52 individuals); black stork (6); Woolly-necked stork (148) and Asian open bill stork (363). However, present study reported Lesser adjutant stork (72 individuals); Black stork (12); Woolly-necked stork (7) and Asian open bill stork (252). Similarly, the study on population status and diversity of wetland birds in Rapti and Narayani rivers reported 46 species of water birds including 12 species of water fowl in 2011 (Khadka et al., 2017). This study recorded comparatively higher number of waterfowls. Recent survey of water birds in and around the wetlands of Chitwan National Park shows decline of 1,128 water birds compared to last survey $(10,032)$ (BCN, 2017). A total of 36 species of water birds have been recorded in the Rupa lake, the third largest lake of 
Pokhara valley that represents $19 \%$ of the total 193 wetland-dependent birds found in Nepal Kafle (2008) and Giri \& Chalise (2008) recorded 39 water bird species belonging to 17 families of 5 orders at Phewa lake. Chhetry (2006) reported 98 species of wetland birds belonging to 60 genera and 18 families around the Koshi barrage area. Thapa \& Saund (2012) reported a total of 77 bird species representing 8 orders and 31 families in Jagadishpur reservoir. Kumar \& Gupta (2009) reported 54 species of wetland birds belonging to 36 genera and 15 families distributed in 5 orders around Kurukshetra, India. Hence, wetland of BCF supported more species of wetland bird than Rupa, Phewa and Jagadishpur Reservoir. Comparatively, high water bird diversity and abundance in BCF is mainly due to large and diverse areas of wetlands within a small area. Furthermore, the high diversity of residential and migratory water birds in BCF may reflect its corridor function, connecting lowland and highlands.

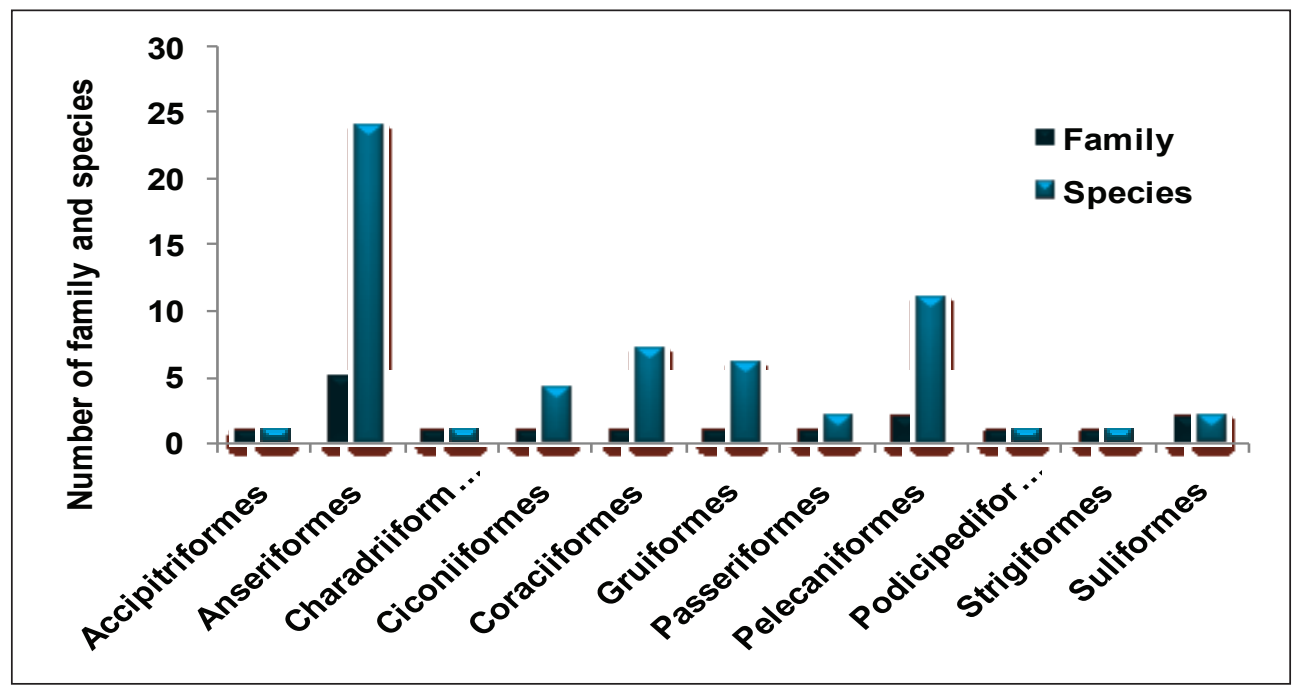

FIG. 2. Taxonomic order wise family and species richness in BCF.

TABLE 1. Checklist of water birds of BCF.

\begin{tabular}{|c|c|c|c|c|}
\hline S.N. & Common name & Scientific name & Abundance & $\begin{array}{l}\text { IUCN } \\
\text { status }\end{array}$ \\
\hline \multicolumn{5}{|c|}{ Order: Accipitriformes, Family: Accipitridae } \\
\hline 1. & Pallas's fish eagle & Haliaeetus leucoryphus Pallas, 1771 & 4 & VU \\
\hline 2. & Grey-headed fish eagle & Icthyophaga ichthyaetus Horsfield, 1821 & 14 & NT \\
\hline \multicolumn{5}{|c|}{ Order: Anseriformes, Family: Anatidae } \\
\hline 3. & Northern pintail & Anas acuta Linnaeus, 1758 & 143 & LC \\
\hline 4. & Common teal & Anas crecca Linnaeus, 1758 & 122 & LC \\
\hline 5. & Mallard & Anas platyrhynchos Linnaeus, 1758 & 76 & LC \\
\hline
\end{tabular}




\begin{tabular}{|c|c|c|c|c|}
\hline 6. & Indian spot-billed duck & Anas poecilorhyncha Forster, 1781 & 121 & LC \\
\hline 7. & Gadwall & Anas strepera Linnaeus, 1758 & 57 & LC \\
\hline 8. & Bar headed goose & Anser indicus Latham, 1790 & 6 & LC \\
\hline 9. & Ferruginous duck & Aythya nyroca Güldenstädt, 1770 & 10 & NT \\
\hline 10. & Lesser whistling-duck & Dendrocygna javanica Horsfield, 1821 & 40 & LC \\
\hline 11. & Little pratincole & Glareola lactea Temminck, 1820 & 15 & LC \\
\hline 12. & Pheasant-tailed jacana & Hydrophasianus chirurgus Scopoli, 1786 & 30 & LC \\
\hline 13. & Goosander & Mergus merganser Linnaeus, 1758 & 53 & LC \\
\hline 14. & Bronze-winged jacana & Metopidius indicus Latham, 1790 & 12 & LC \\
\hline 15. & Cotton pigmy-goose & Nettapus coromandelianus Gmelin, 1789 & 43 & LC \\
\hline 16. & Ruddy shelduck & Tadorna ferruginea Pallas, 1764 & 188 & LC \\
\hline 17. & Common shelduck & Tadorna tadorna Linnaeus, 1758 & 12 & LC \\
\hline 18. & Red-wattled lapwing & Vanellus indicus Boddaert, 1783 & 54 & LC \\
\hline 19. & Yellow-wattled lapwing & Vanellus malarbaricus Boddaert, 1783 & 81 & LC \\
\hline \multicolumn{5}{|c|}{ Order: Charadriiformes, Family: Scolopacidae } \\
\hline 20. & Green sandpiper & Tringa ochropus Linnaeus, 1758 & 158 & LC \\
\hline \multicolumn{5}{|c|}{ Order: Ciconiiformes, Family: Ciconiidae } \\
\hline 21. & Asian openbill stork & Anastomus oscitans Boddaert, 1783 & 252 & LC \\
\hline 22. & Woolly-necked stork & Ciconia episcopus Boddaert, 1783 & 7 & VU \\
\hline 23. & Black stork & Ciconia nigra Linnaeus, 1758 & 12 & LC \\
\hline 24. & Lesser adjuntant stork & Leptoptilos javanicus Horsfield, 1821 & 72 & VU \\
\hline \multicolumn{5}{|c|}{ Order: Coraciiformes, Family: Alcedinidae } \\
\hline 25. & Common kingfisher & Alcedo atthis Linnaeus, 1758 & 89 & LC \\
\hline 26. & Blue-eared kinghfisher & Alcedo meninting Horsfield, 1821 & 65 & LC \\
\hline 27. & Pied kingfisher & Ceryle rudis Linnaeus, 1758 & 8 & LC \\
\hline 28. & $\begin{array}{l}\text { Black-capped } \\
\text { kingfisher }\end{array}$ & Halcyon pileata Boddaert, 1783 & 12 & LC \\
\hline 29. & $\begin{array}{l}\text { White-breasted } \\
\text { kingfisher }\end{array}$ & Halcyon smyrnensis Linnaeus, 1758 & 46 & LC \\
\hline 30 & Stork-billed kingfisher & Pelargopsis capensis Linnaeus, 1766 & 9 & LC \\
\hline \multicolumn{5}{|c|}{ Order: Gruiformes, Family: Rallidae } \\
\hline 31. & Brown crake & Amaurornis akool Sykes, 1832 & 46 & LC \\
\hline 32. & $\begin{array}{l}\text { White-breasted } \\
\text { waterhen }\end{array}$ & Amaurornis phoenicurus Pennant, 1769 & 146 & LC \\
\hline 33. & Common coot & Fulica atra Linnaeus, 1758 & 55 & LC \\
\hline 34. & Common moorhen & Gallinula chloropus Linnaeus, 1758 & 17 & LC \\
\hline
\end{tabular}


Adhikari et al: Diversity and conservation threats of water

\begin{tabular}{|c|c|c|c|c|}
\hline 35. & Purple swaphen & Porphyrio porphyrio Linnaeus, 1758 & 144 & LC \\
\hline 36. & Ruddy-breasted crake & Zapornia fusca Linnaeus, 1766 & 87 & LC \\
\hline \multicolumn{5}{|c|}{ Order: Passeriformes, Family: Muscicapidae } \\
\hline 37. & $\begin{array}{l}\text { White caped water } \\
\text { redstart }\end{array}$ & Phoenicurus leucocephalus Vigors, 1831 & 35 & LC \\
\hline 38. & $\begin{array}{l}\text { Plumbeous water } \\
\text { redstart }\end{array}$ & Rhyacornis fuliginosus Vigors, 1831 & 23 & LC \\
\hline \multicolumn{5}{|c|}{ Order: Pelecaniformes, Family: Ardeidae } \\
\hline 39. & Grey heron & Ardea cinerea Linnaeus, 1758 & 64 & LC \\
\hline 40. & Intermediate egret & Ardea intermedia Wagler, 1829 & 46 & LC \\
\hline 41. & Purple heron & Ardea purpurea Linnaeus, 1766 & 22 & LC \\
\hline 42. & Indian pond heron & Ardeola grayii Sykes, 1832 & 146 & LC \\
\hline 43. & Green backed heron & Butorides striata Linnaeus, 1758 & 176 & LC \\
\hline 44. & Great white egret & Casmerodius albus Linnaeus, 1758 & 58 & LC \\
\hline 45. & Little egret & Egretta garzetta Linnaeus, 1766 & 306 & LC \\
\hline 46. & Cinnamon bittern & Ixobrychus cinnamomeus Gmelin, 1789 & 28 & LC \\
\hline 47. & Yellow bittern & Ixobrychus sinensis Gmelin, 1789 & 40 & LC \\
\hline 48. & $\begin{array}{l}\text { Black-crowned night } \\
\text { heron }\end{array}$ & Nycticorax nycticorax Linnaeus, 1758 & 76 & LC \\
\hline \multicolumn{5}{|c|}{ Family: Threskiornithidae } \\
\hline 49. & Black ibis & Pseudibis papillosa Temminck, 1824 & 32 & LC \\
\hline \multicolumn{5}{|c|}{ Order: Podicipediformes, Family: Podicipedidae } \\
\hline 50. & Black-necked grebe & Podiceps nigricollis Brehm, 1831 & 45 & LC \\
\hline \multicolumn{5}{|c|}{ Order: Strigiformes, Family: Strigidae } \\
\hline 51. & Brown fish owl & Ketupa zeylonensis Gmelin, 1788 & 25 & LC \\
\hline \multicolumn{5}{|c|}{ Order: Suliformes, Family: Anhingidae } \\
\hline 52. & Oriental darter & Anhinga melanogaster Pennant, 1769 & 23 & NT \\
\hline \multicolumn{5}{|c|}{ Family: Phalacrocoracidae } \\
\hline 53. & Great cormorant & Phalacrocorax carbo Linnaeus, 1758 & 174 & LC \\
\hline 54. & Little cormorant & Phalacrocorax niger Vieillot, 1817 & 39 & LC \\
\hline
\end{tabular}

(VU=Vulnerable, NT= Near Threatened, LC= Least Concern)

The species diversity of water birds in eight different study sites indicates the higher diversity in Rapti river $(H=3.403)$, followed by Beeshazari lake system $(H=3.401)$, Batulpokari lake area (Shannon's index of diversity $H=3.377$ ) and so on. The least diversity was in Gundremandre lake $(H=2.21)$. Due to the livestock grazing pressure and human disturbance, the species diversity in Khageri river was low in comparison to other rivers $(H=2.926)$. Similarly, the species dominance was more in Gundremandre lake (Dominance index= 0.1882) than 
Beeshhazari $(D=0.046, J=0.89)$, Batulpokhari $(D=0.04132)$, that indicates low species diversity in Gundramadre lake (Simpson index $1-D=0.811$, Evenness $=0.56$, Jacob's equitability index= 0.764 ) (table 2). Similar type of study conducted by Ali et al. (2011) found a high species diversity of water birds $(H=3.31$ and $1-D=0.94)$ in Mangala Dam, India. Giri \& Chalise (2008) found the highest diversity of birds $(H=2.6228)$ in February and lowest $(H=1.2014)$ in June in the Phewa Lake. These findings indicated that BCF possess a low species diversity of water birds compared to the high diversity of wetlands available (e.g., rivers and lakes).

TABLE 2. Water birds species diversity and dominance indices in BCF.

\begin{tabular}{|c|c|c|c|c|c|c|c|}
\hline Study sites & $\begin{array}{l}\mathscr{0} \\
\frac{\mathbb{0}}{0} \\
\mathbb{d} \\
\frac{0}{0} \\
\frac{0}{0} \\
\mathbf{0} \\
\mathbf{z}\end{array}$ & 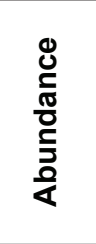 & 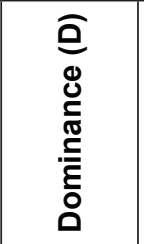 & 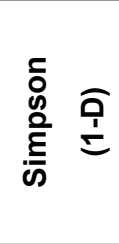 & 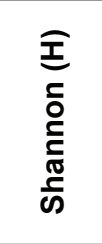 & 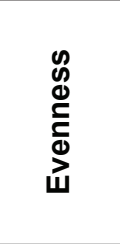 & 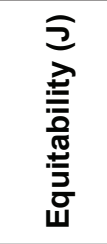 \\
\hline Rapti river & 50 & 1112 & 0.04763 & 0.9524 & 3.403 & 0.6013 & 0.87 \\
\hline Beeshhazari lake & 45 & 999 & 0.04672 & 0.9533 & 3.401 & 0.6667 & 0.8935 \\
\hline Batulpokhari & 39 & 552 & 0.04132 & 0.9587 & 3.377 & 0.7512 & 0.9219 \\
\hline Budhirapti & 39 & 329 & 0.06969 & 0.9303 & 3.103 & 0.5706 & 0.8469 \\
\hline Devnagar & 27 & 245 & 0.05266 & 0.9473 & 3.106 & 0.8271 & 0.9424 \\
\hline Gundremandre & 18 & 133 & 0.1882 & 0.8118 & 2.21 & 0.5063 & 0.7645 \\
\hline Khageri river & 22 & 83 & 0.0614 & 0.9386 & 2.926 & 0.8481 & 0.9467 \\
\hline $\begin{array}{l}\text { Rhinolake and } \\
\text { association }\end{array}$ & 23 & 183 & 0.08615 & 0.9139 & 2.725 & 0.663 & 0.8689 \\
\hline
\end{tabular}

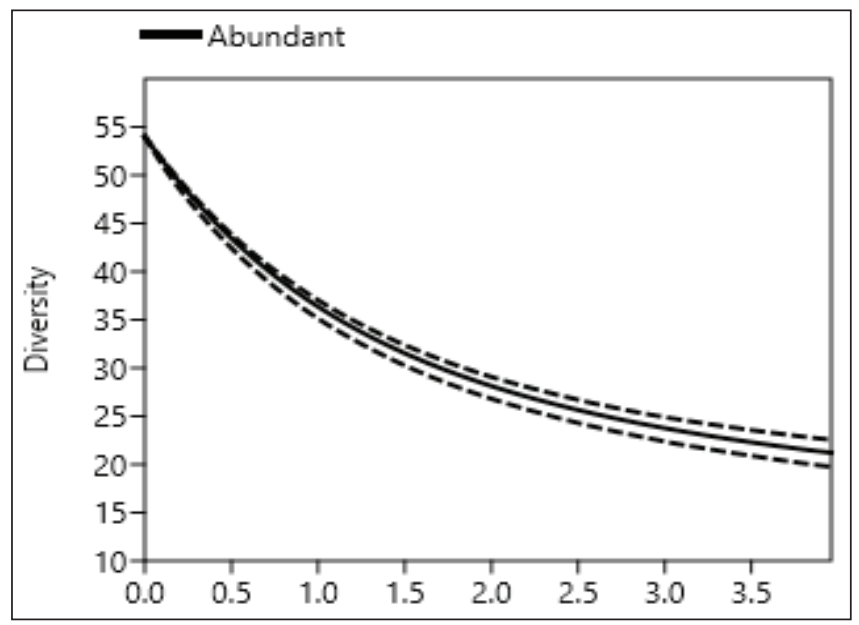

FIG. 2. Species Diversity profiles of water birds in BCF at $95 \%$ confidence interval. 


\section{Species accumulation curves.}

Arrhenius (1921) was the first to fit a model to data on the increase in number of species with increased size of the area sampled. It is important to distinguish between the species-area relationships (Ugland et al., 2003). An ordinary count of number of species in a sample is usually a biased underestimate of the true number of species in the environment, simply because increasing the sampling effort (through counting more individuals, examining more sampling units, or sampling a larger area) inevitably increases the number of species (Gotell \& Chao, 2013). This effect illustrated in a species accumulation curve, in which $x$-axis is the number of individuals recorded and $y$-axis is the number of species observed or species richness.

The water bird species accumulation curve was exponentially increased up to 1,000 individuals, slowly increased up to 1,500 individuals, very slowly increased up to 3,664 (fig. 3). The encounter rates of rare and the endangered species of water birds were very low, where common species were encountered very high. The curve continues to rise as more individuals are sampled, but the slope becomes shallower because progressively more sampling effort is required to detect the rare species (Tokeshi \& Schmid, 2002). These imperial findings suggest that BCF harbors critical populations of many rare and threatened water birds.

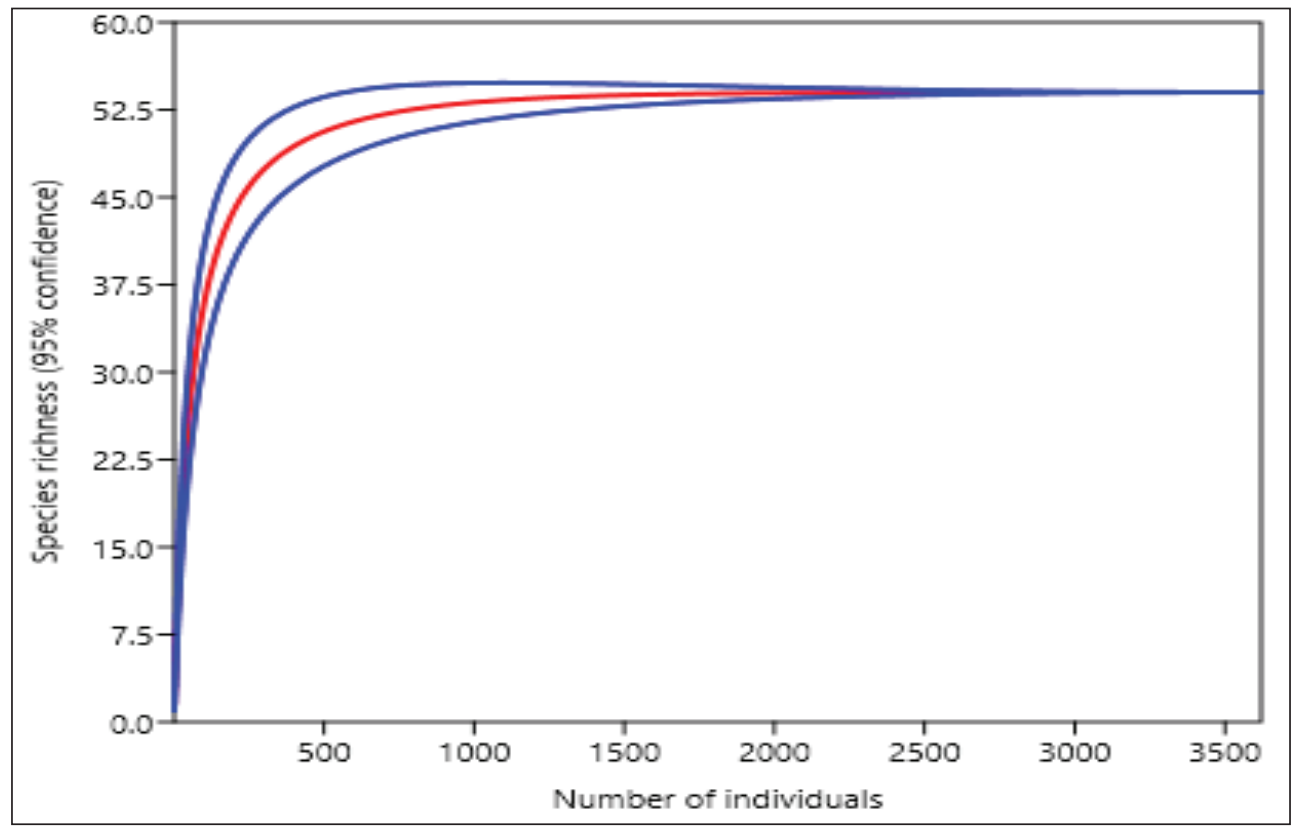

FIG. 3. Species accumulation curve. The curve was generated by assuming an assemblage of 54 species whose relative abundances were created from a broken stick distribution (Tokeshi \& Schmid, 2002). The x-axis is the number of individuals and the $y$-axis is species richness at $95 \%$ confidence limit. The shape of this species accumulation curve is typical, it rises rapidly at first as the common species are initially encountered, and then continues to rise very slowly, as much more sampling is needed to encounter all of the rare species. 


\section{Habitat association of water birds}

More than $80 \%$ area of BCF is covered by Shorea forest and rest of the area includes grasslands, riverine forest, mixed forest and wetlands. The peripheries of Beeshazari lake, Batulpokhari lake and Rhino lake are mainly surrounded by Shorea forest. Khageri, Budhirapti and Gundremandre lake areas are associated with riverine type of vegetation while most parts of Rapti river are associated with sal forest, riverine forest and tall grassland. The correlation matrix obtained from principal component analysis (PCA) of species richness in different habitats showed that sal forest was utilized very less as compared to its availability. However, riverine forest, open areas and farmlands were positively selected by the water birds (fig. 4). Present study confirms the role of habitats such as water bodies and vegetation cover affect the abundance of water bird (Ramachandran et al., 2017). Avian species diversity in different habitat types in and around North Nandi Forest, Kenya reported a significant difference in bird abundance across the four habitats (indigenous forest, disturbed forest, plantation forest and farmlands: $F=15.141, P \leq 0.05$ ) (Bett et al., 2016) similar to our study (Welch $F=907.9, d f=$ $1813, p<0.0001)$.

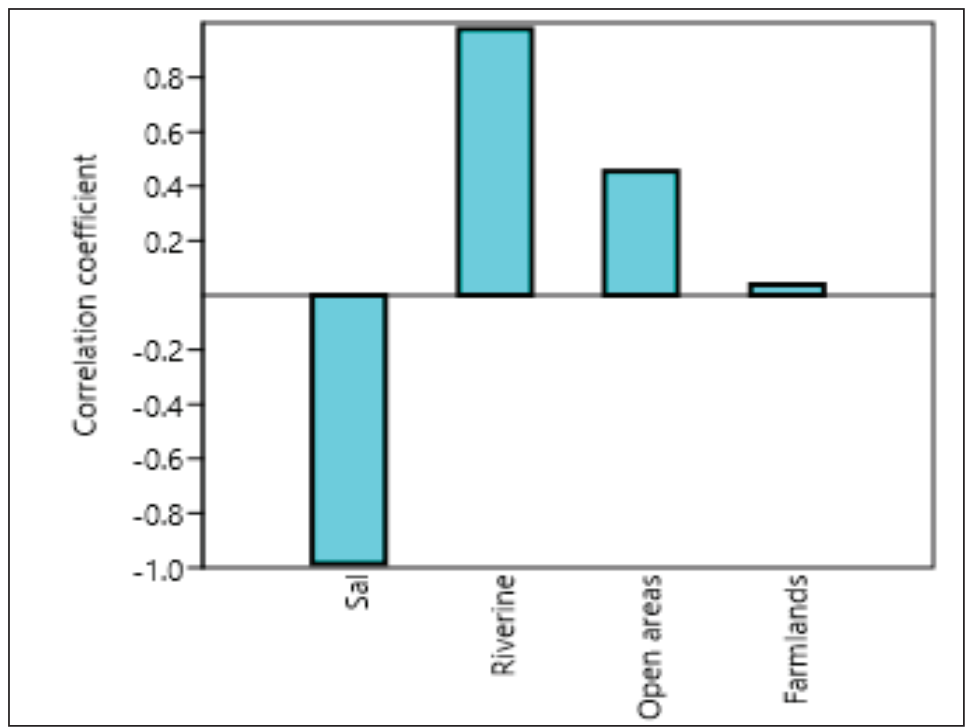

FIG. 4. Correlation coefficients obtained from PCA of species distribution in various habitats showed the various ranges of strength of preference with different habitat associations of wetlands.

\section{Conservation threats of water birds in BCF}

Present study found three globally vulnerable species Haliaeetus leucoryphus (Pallas's fish eagle), Leptoptilos javanicus (Lesser adjuntant stork), Ciconia episcopus (Woolly-necked stork) and three globally near-threatened species Icthyophaga ichthyaetus (Grey-headed fish eagle), Aythya nyroca (Ferruginous duck), and Anhinga melanogaster (Oriental darter) (IUCN, 2017; BCN \& DNPWC, 2011; Bhattarai, 2012). Pallas's fish eagle and Lesser adjuntant stork 
enlisted in vulnerable category since 1994 and Woolly-necked stork enlisted in same category since 2014 (IUCN, 2017). Similar type of study by Sharma (2004) recorded twelve nationally threatened species of birds including two critically endangered birds in the Barandabar corridor forest. Baral \& Inskipp (2009) found a total of 15 globally threatened and 13 nearthreatened species in Suklaphanta Wildlife Reserve and BCN \& DNPWC (2011) described 149 bird species (17\%) of Nepal's birds as nationally threatened that included 61 critically endangered species, 38 endangered and 50 vulnerable.

Fishing, livestock grazing pressure and human disturbances were the major threats to the water birds in this area. The abundance of species was greatly affected by the number of fisherman presence for collection of prey species of water birds (e.g., fishes, snails etc.). The relationship between number of fishermen and abundances of water bird species showed negative relationship $(r=-0.3907, t=10.6, P<0.0001)$ (fig. 5). Likewise, number of livestock present in the habitats of water birds caused significantly negative effect on species richness and abundance of water birds $(r=-0.276, t=6.63, P=0.0009$ ) (fig. 6). Zou et al. (2017) found the great influence of microhabitat condition including forage availability in human dominated wetlands (e.g., human disturbance, habitat alternation and degradation, mudflats) for water birds especially winter visitors in Caisang Lake particularly at other Ramsar wetlands. Similar problems also occurred in Rapti river flood plains (e.g., loss of a large patch of riverine forest and grasslands) and Beeshazari lake system (e.g., depleted Satrahazar and Sorahazar lakes). Many water birds including migratory species are now threatened with extinction due to past and ongoing destruction, and degradation of wetlands (Szabo \& Mundkur, 2017). Recent studies show that climate change and invasive species are two major drivers of ecosystem degradation and biodiversity loss (Lamsal et al., 2017).

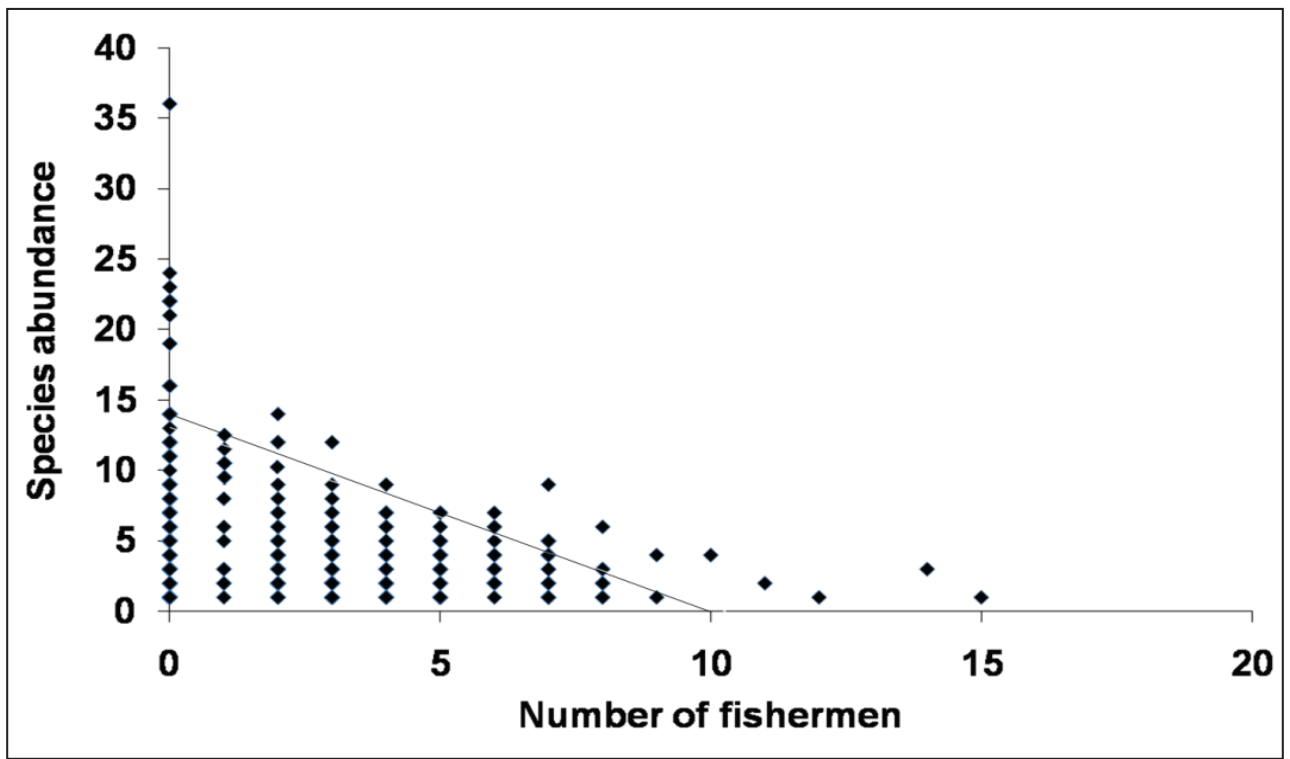

FIG. 5. Effect of fishermen on the occurrence and abundance of water birds in BCF $(r=-0.3907, t=10.6, P<0.0001)$. 


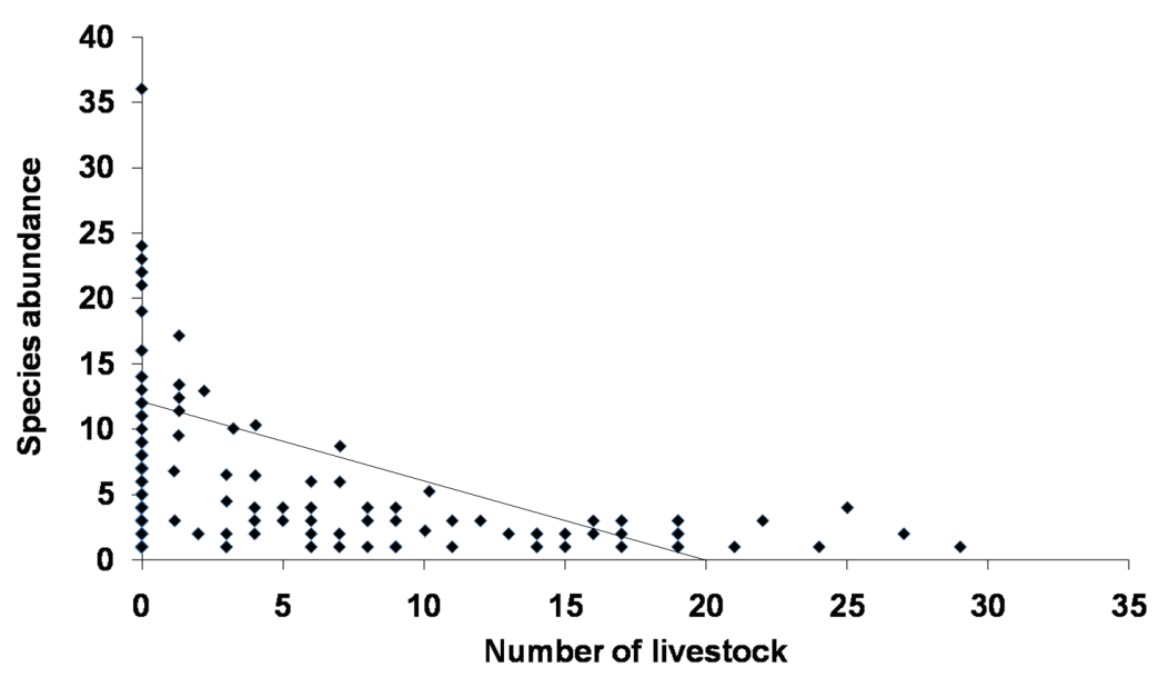

FIG. 6. Effect of livestock pressure on the occurrence and abundance of water birds in BCF $(r=-0.276, t=6.63, P=0.0009)$.

This study recorded 3664 individuals of water birds belonging to 11 orders, 13 families and 54 species in Barandabhar corridor forest. Among them, the highest number of species were belonged to order Anseriformes (17 species) followed by Pelecaniformes (11 species), Coraciiformes (6 species), and Gruiformes (6 species). This study found three globally vulnerable water birds Pallas's fish eagle (Haliaeetus leucoryphus), Lesser adjuntant stork (Leptoptilos javanicus) and Woolly-necked stork (Ciconia episcopus) together with nearthreatened Grey-headed fish eagle (Icthyophaga ichthyaetus), Ferruginous duck (Aythya nyroca), and Oriental darter (Anhinga melanogaster). The water bird diversity in eight different wetlands indicating the highest diversity in Rapti river $(H=3.403)$, followed by Beeshazari lake system $(H=3.401)$, Batulpokari lake area $(H=3.377)$ and others. The least species diversity of water birds was found in Gundremandre lake $(H=2.21)$. Similarly, the species dominance was more in Gundre Mandre lake (Dominance index $=0.1882)$ than Beeshhazari $(D=0.046)$ and Batulpokhari $(D=0.04132)$. The species richness in different habitat association with wetlands showed that Shorea forest association was utilized very less as compared to its availability. Human (fishermen: $r=-0.3907, t=10.6, P<0.0001)$ and livestock pressure $(r=$ $-0.276, t=6.63, P=0.0009)$ caused the significant impact on the occurrence of water birds in many parts of the study sites. The study found annual flooding in the rivers (e.g., Rapti, Budhirapti and Khageri rivers), human disturbance (e.g., livestock grazing and fishing), habitat loss and degradation, declining water quality and quantity caused by eutrophication and chemical pollution are the major drivers of water bird communities in BCF. Therefore, strict habitat protection, regular monitoring, adaptive management of wetlands in both protected and unprotected areas and preservation and restoration of wetlands with minimum human pressure are essential for maintaining functional wetland ecosystems and combating declines 
of wetland-dependent residential and migratory water birds in BCF.

\section{ACKNOWLEDGEMENTS}

This research is a part of the Conservation Watch Project of Himalayan Environment and Public Health Network (HEPHN) under a survey of water birds in the Chitwan District. The data were collected under the rules and guidelines of the Department of National Parks and Wildlife Conservation and Chitwan National Park and District Forest Office Chitwan. We would like to thank all the members of survey team and student volunteers for their support and dedication to water bird conservation.

\section{REFERENCES}

ALI Z; SHELLY, S Y; BIBI, F; JOSHUA, G; KHAN, A M; KHAN, B N; AKHTAR, M (2011) Peculiarities of Mangla reservoir: biodiversity with sustainable use options. Animal and Plant Science 21(2): 372-380.

ARYAL, A; BRUNTON, D; PANDIT, R; SHRESTHA, T K; LORD, J; KOIRALA, R K; THAPA, Y B; ADHIKARI, B; JI, W; RAUBENHEIMER, D (2012) Biological diversity and management regimes of the northern Barandabhar forest corridor: an essential habitat for ecological connectivity in Nepal. Tropical Conservation Science 5(1): 38- 49.

ARRHENIUS, O (1921) Species and area. Journal of Ecology 9: 95-99.

BARAL, H S (2009) Protected birds of Nepal: a review of their status, distribution and habitat. The Initiation 3: 66-80.

BARAL, H S; REGMI, U R; POUDYAL, L P; ACHARYA, R (2012) Status and conservation of birds in Nepal. Biodiversity conservation in Nepal, a success story, DNPWC, Kathmandu, Nepal; pp 61-90.

BARAL, H S; INSKIPP, C (2009) The Birds of Suklaphanta Wildlife Reserve, Nepal. Our Nature 7: 56-81. Doi: 103126/onv7i12554.

BARAL, H S (2005) Birds of Koshi Department of National Parks and Wildlife Conservation and Bird Conservation Nepal, Kathmandu, Nepal.

BARAL, H S; INSKIPP, C (2005) Important bird areas in Nepal: key sites for conservation. Bird Conservation, Kathmandu, Nepal.

BCN, DNPWC (2011) The state of Nepal's birds 2010. Bird Conservation Nepal and Department of National Parks and Wildlife Conservation, Kathmandu, Nepal.

BCN (2017) National water bird survey. Bird Conservation Nepal, Nepal Orninthological Union and Wetlands International, The Netherlands.

BETT, M C; MUCHAI, M; WAWERU, C (2016) Avian species diversity in different habitat types in and around North Nandi Forest, Kenya. African Journal of Ecology 54(3): 342-348.

BHATTARAI, B P (2012) Distribution and diversity of storks in the adjoining areas of Chitwan National Park, Nepal. In KINDLMANN, P (ed) Himalayan biodiversity in the changing world. Springer, Dordrecht, The Netherlands; pp 97-114.

BIBBY, C J; BURGRESS, N D; HILL, D A (2000) Birds'census techniques. Birdlife International Academic press, London, UK; $215 \mathrm{pp}$.

BULL, J (1974) Birds of New York state. Doubleday/ Natural History Press, Cornell University Press, USA; $622 \mathrm{pp}$. 
CHHETRI, D T (2006) Diversity of wetland birds around the Koshi barrage area. Our Nature 4: 91-95.

CNP (2017) Biodiversity of Chitwan National Park. Available: http://chitwannationalparkgovnp/indexphp/ biodiversity.

DIENI, JS; JONES, SL (2002)A field test of the area search method for measuring breeding bird populations. Journal of Field Ornithology 73(3): 253-257. Available: https://doiorg/101648/0273-8570-733253.

DIENI, J S; JONES, S L (2004) Roadside bias in point count surveys at Arrow Wood National Wildlife Reguge, North Dakota. The Prairie Naturalist 36(4): 204-211.

DNPWC (2017) Department of National Parks and Wildlife Conservation, Nepal. Available: http:// dnpwcgovnp.

GIRI, B; CHALISE, M K (2008) Seasonal diversity and population status of water birds in Phewa lake, Pokhara, Nepal. Journal of Wetlands Ecology 1(2): 3-7.

HAMMER, Ø; HARPER, D A T; RYAN, P D (2001) Past: paleontological statistics software package for education and data analysis. Palaeontologia Electronica. Available: http://palaeo-electronicaorg.

INSKIPP, C; INSKIPP, T; GRIMMETT, R; BARAL, H S (2008) Birds of Nepal. Bird Conservation, Nepal, Kathmandu, Nepal.

IUCN (2017) The IUCN Red List of Threatened Species. Version 2017-3 Available: wwwiucnredlistorg.

IUCN NEPAL (2004) A review of the status and threats to wetlands in Nepal. IUCN Nepal, Nepal.

KAFLE, G, COTTON, M; CHAUDHARY, J R; PARIYAR, H; ADHIKARI, H, BOHORA, S B, CHAUDHARY, U; RAM, A; REGMI, B (2008) Status of and threats to water birds of Rupa lake, Pokhara, Nepal. Journal of Wetlands Ecology 1: 9-12.

KHADKA, B B; ACHARYA, P M; RAJBHANDARI, S L (2017) Population status and species diversity of wetland birds in the Rapti and Narayani rivers and associated wetlands of Chitwan National Park, Nepal. Journal of Threatened Taxa 9(6): 10297-10306.Available: http://doiorg/1011609/jott 236496 1029710306.

KHAN, B N; ALI, Z (2015) Assessment of birds' fauna, occurrence status, diversity indices and ecological threats at Mangla dam. The Journal of Animal \& Plant Sciences 25(3): 397-403.

KUMAR, A; SATI, J P; TAK, P C; ALFRED, J R B (2005) Handbook on Indian wetland birds and their conservation. Zoological Survey of India, Kolkata, India; xxvi+468 pp.

LAMICHHANE, S; KANDEL, R C; POKHERAL, C P; DAHAL T P; BHATTARAI, S (2016) Biodiversity profile of Beeshazar and associated lakes, Chitwan. DNPWC, CNP, NTNC, Norad, Ramsar site international.

LAMSAL, P; KUMAR, L; ATREYA, K; PANT, K P (2017) Vulnerability and impacts of climate change on forest and freshwater wetland ecosystems in Nepal: a review. Ambio 46(8): 915-930.

Gotell, N J; Chao, A (2013) Measuring and estimating species richness, species diversity, and biotic similarity from sampling data. In LEVIN S A (ed) Encyclopedia of biodiversity 5: 195-211. Academic Press, Waltham, MA, USA; 195-211. (2nd edition).

NLCDC (2017) Ramsar sites of Nepal. National Lake Conservation and Development Committee. Available: http://nepallakegovnp/2017/05/01/ramsar-sites-of-nepal/.

NTNC (2003) Ecological assessment of Barandabhar corridor forest final report. National Trust for Nature Conservation (NTNC), Biodiversity Conservation Center, Tiger, Rhino Conservation Project, Sauraha, Chitwan, Nepal. 
RAJPAR, M N; ZAKARIA, M (2010) Density and diversity of water birds and terrestrial birds at Paya Indah Wetland Reserve, Selangor Peninsular Malaysia. Journal of Biological Sciences 10 (7): 658-666.

RAJPAR, M N; ZAKARIA, M (2011) Effects of water level fluctuation on waterbirds distribution and aquatic vegetation composition at natural wetland reserve, Peninsular Malaysia. International Scholarly Research Network Ecology 2011: 1-13.

RAMACHANDRAN, R; KUMAR, A; SUNDAR, K S G; BHALLA, R S (2017) Hunting or habitat? Drivers of water bird abundance and community structure in agricultural wetlands of southern India. Ambio. Doi 10.1007/s13280-017-0907-9.

SHARMA, H K (2004) Diversity of threatened birds and their conservation threats in Barandabhar corridor forest, Chitwan. MSc thesis, Central Department of Zoology, Tribhuvan University, Kirtipur, Kathmandu, Nepal.

SHRESTHA, T K (2003) Birds of Nepal, Vol I and II. B Shreatha Publication, Kathmandu, Nepal.

SHRESTHA, T K (2016) Wildlife of Nepal. B Shrestha Publication, Kathmandu, Nepal.

SIEGEL, R B (2009) Methods for monitoring land birds. A review commissioned by Seattle city light's wildlife research advisory committee (2000) Natural Resource Report NPS/NCCN/NRR-2009/074.

SZABO, J K; MUNDKUR, T (2017) Conserving wetlands for migratory water birds in south Asia. In PRUSTY, B A K; CHANDRA, R; AZEEZ, P A (eds) Wetland science: perspectives from south Asia. Springer New Delhi, India; pp 105-127.

THAPA, T B (2011) Habitat suitability evaluation for Leopard (Panthera pardus) using remote sensing and GIS in and around Chitwan National Park, Nepal. PhD thesis, Saurashtra Univesrsity, Rajkot, Gujarat, India.

THAPA, V (2002) Habitat heterogeneity and distribution of some ungulate prey species in Barandabhar forest, Chitwan, Nepal. MSc thesis. Center of International Environment and Development Studies (NORAGRIC), Agriculture University of Norway (NLH), Norway.

THAPA, J B; SAUND, T B (2012) Water quality parameters and bird diversity in Jagdishpur reservoir, Nepal. Nepal Journal of Science and Technology 13(1): 143-155.

TOKESHI, M; SCHMID, PE (2002) Niche division and abundance: an evolutionary perspective. Population Ecology 44: 189-200.

UGLAND, K I; GRAY, J S; ELLINGSEN, K E (2003) The species-accumulation curves and estimation of species richness. Journal of Animal Ecology 72(5): 888-897.

ZOU, Y A; PAN, B H; ZHANG, H; ZHANG, P Y; YAO, Y; LIU, X K; GAO, D L; XIE, Y H (2017) Impacts of microhabitat changes on wintering water bird populations. Scientific reports 7(1): 139-34. 